States at the Limit: Tracing Contemporary StateSociety Relations in the Borderlands of Southeastern Turkey

Leila M. Harris

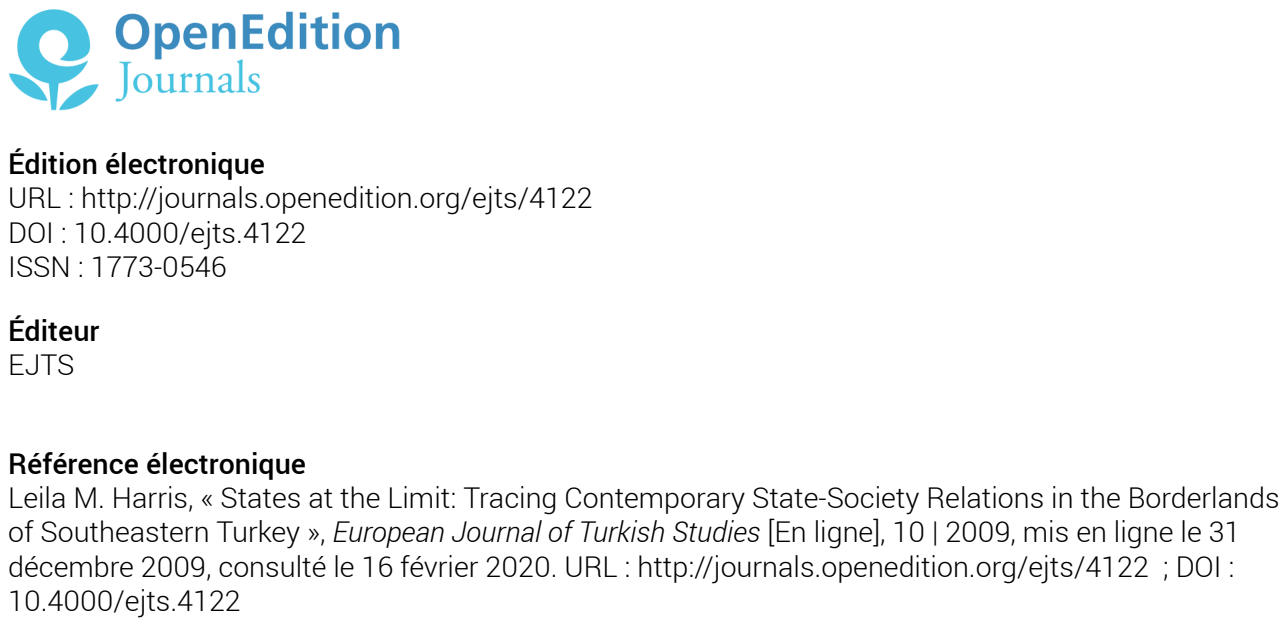

Ce document a été généré automatiquement le 16 février 2020.

(c) Some rights reserved / Creative Commons license 


\section{States at the Limit: Tracing Contemporary State-Society Relations in the Borderlands of Southeastern Turkey}

Leila M. Harris

1 Ali lives in an Arabic speaking village of the Harran plain ${ }^{1}$ and owns a small plot of land with his brother (17 decares). ${ }^{2}$ The brothers recount that they have had difficulty with weeds this year. Ali suggests that this is due to the fact that they haven't rotated their crops. His brother disagrees, and says it is because the state subsidy for pesticides associated with cotton is insufficient, so they only had enough money to apply pesticides once. Despite these problems, they consider themselves to have benefited tremendously from irrigation. 'With one year's harvest, I now earn enough to buy a tractor,' Ali says, explaining that 'culture' and 'development' have also come to rural areas with state irrigation provision.

2 Amit lives in a Kurdish-speaking village a few miles to the west of Ali. As someone who does not own land and who had previously been engaged in herding sheep and goats on the plain, he and his family have very different experiences of irrigation. He explains, 'It was said that GAP ${ }^{3}$ is happiness, GAP is survival, but it has been a suicide pill for those of us engaged in animal husbandry. It prepared our end. Right now, (speaking about) GAP gives me discomfort.' Others who had also relied on animal husbandry selling yoghurt, cheese, and animals for income, and using wool, meat, and dairy products for family needs- tell of increasing difficulties in terms of being able to make ends meet since the coming of widespread canalet irrigation. With fields now dedicated to irrigated cotton production, there is no longer space available to graze animals.

3 In another nearby Kurdish speaking village, Mufa takes great pride in showing me the documentation of the state subsidy he will receive for last year's cotton crop. Although he only owns 25 decares of his own land, he is entitled to 630 USD of cotton subsidy (based on 9 cents per kilo of cotton, the subsidy in 2001). This is significant money in a 
plain where average household incomes are estimated as less than $\$ 5,000$ a year. ${ }^{4}$ Mufa believes that without the subsidy farmers would not be able to afford pesticides, irrigation water, or other expenses associated with cotton, and would likely revert to growing wheat or other dryland crops. He believes the state must benefit from cotton production; otherwise they would not pay him to grow it.

\section{Towards an Ethnographic Approach to States At their limits}

'A state exists chiefly in the hearts and minds of its people; if they do not believe it

is there, no logical exercise will bring it to life' (Joseph Strayer, 1970: 5)

4 As suggested by the brief vignettes above, state delivery of irrigation to the Harran plain in southeastern Turkey over the past decade as part of the large-scale GAP project has had dramatic and varied implications for village life, crop selection and rural economies. My purpose here is to read the Turkish state and trace shifting state-society relations through villager narratives in the Harran plain of the Southeastern Anatolia region-a border region that has been historically and geographically marginalized since the initial establishment of the Turkish Republic (see Map 1, below). The time period under examination is also significant as the region is undergoing rapid and extensive change as part of the large-scale GAP project. Tracing variable responses and interpretations of the 'state' in a region experiencing important state-led developmental changes reveals the changing horizontal reach of the state (extending into regions and spaces where the state previously had little presence) and also shifting verticality of the state (providing a sense of the shifting intensities of state-society interactions in the village spaces of this border area). The evidence offered is also suggestive of changing state-society relations in ways that are potentially important for issues of the legitimacy of the Turkish state, and also shifting possibilities related to the Kurdish question -an especially critical issue given the history and geography of this region, and lingering conflicts related to separatist movements and the Turkish state response. 


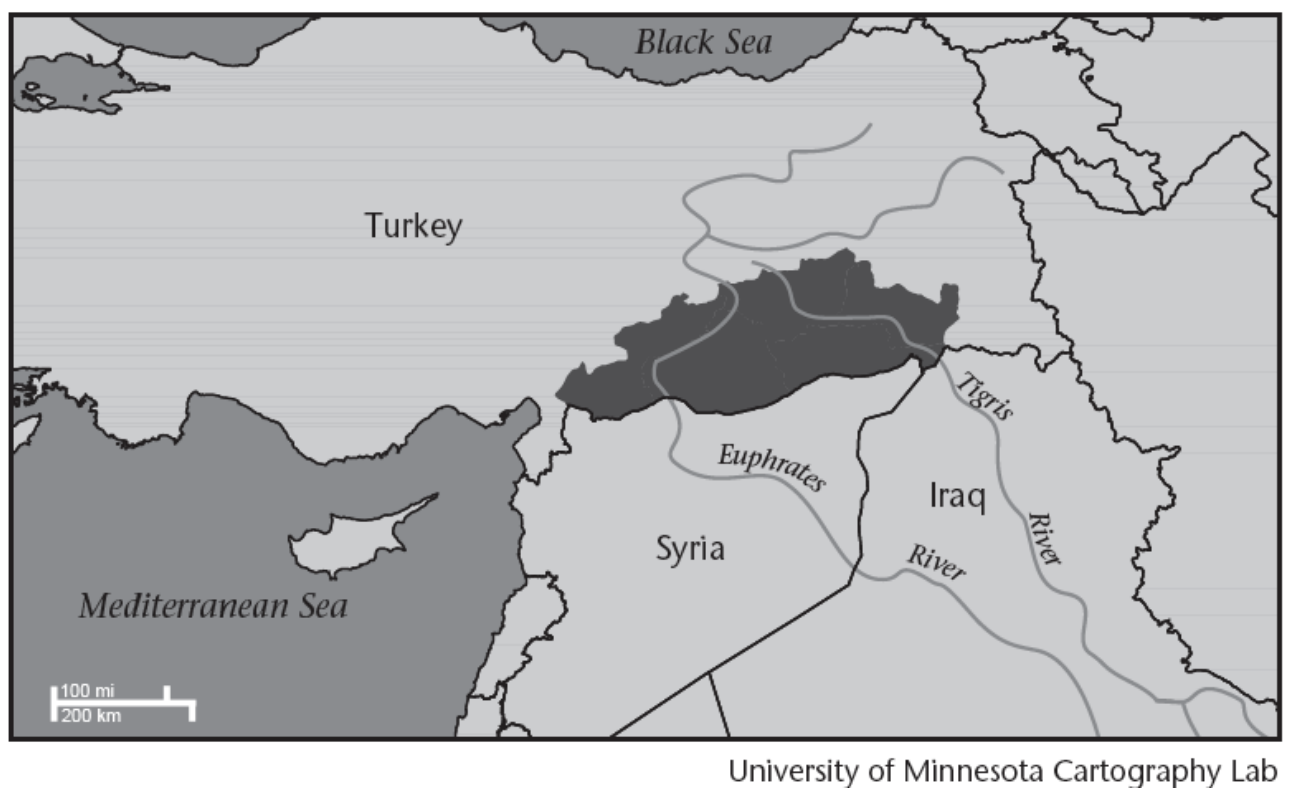

While I invoke 'the Turkish state', reading the state in relation to rural residents' narrations is necessarily to also recognize 'the state' as a non-distinct, indeterminate contested sphere. Indeed, insights to be gained from this analysis are due precisely to the fact that I investigate and situate the state in relation to its most unlikely and contested 'sites' and articulations -through that of the small, rural, marginalized, ethnically diverse villages of Turkey's southeast. The extent to which the state 'appears' in this region, and is narrated by villagers living in this region, reveals something about the degree of success, vertically and horizontally, of state and nationbuilding projects in the contemporary moment.

My approach to questions of state consolidation, nation-building, and citizenship draws heavily from a growing body of work on 'ethnographies of the state' (e.g. Gupta 1995; Moore 1993; Navaro-Yashin 2002; Secor 2007). In brief, ethnographic approaches to states detail the everyday practices, encounters, and lived effects of the state. As Navaro-Yashin notes, an ethnographic approach to states allows an analysis of 'people and the state, not as an opposition, but as the same domain (2)' (see also Migdal 2001, 2004 for overview of state-society approaches). My study builds on these works in reading how the state is lived and articulated in everyday life. However, I also extend these works by picking up on Gupta's (1995) interest in understanding the ways that the state is experienced and lived in rural spaces. Pushing this a bit further, I provide an analysis of evolving state-society relations in spaces that are not only marginal in terms of their rurality, ${ }^{5}$ but more centrally, with respect to state and nation-building projects over time. In the Turkish example, the contemporary southeast is emblematic in this regard -as a culturally, politically, and economically contested region that has increasingly frustrated Turkish state and nation-building since the establishment of the Republic in 1923 (Kiriş̧̧i \& Winrow 1997; Dahlman 2002; Harris 2002, 2008a). As such, rural spaces of the southeast can be understood not only as marginal to Turkish state and nation-building, but also as sites of open contestation. I argue that it is only by reading the 'state at its limits' in those border spaces where Turkish state and nationbuilding have often been contested, frustrated, and even overtly challenged (ibid) that 
we can begin to trace and understand both illustrative and exceptional dimensions of state-society relations and understandings.

The analysis provided focuses on the case of irrigation delivery as among the recent changes that have fundamentally altered everyday village life in the southeast, and, with it, the ever-dynamic character of state-society encounters. The reach of the state is analyzed horizontally, in terms of infiltrating new spaces and life practices, and also vertically, in terms of intensified interaction, for instance associated with increased incorporation of rural residents into the Turkish economy or increased dependence of villagers on state services. Narratives analyzed include both ways that villagers invoke the state in relation to questions about irrigation and GAP-related changes, as well as following questions that directly dealt with the state and villagers' experiences of state programs and services. ${ }^{6}$ Taken together, my aim is to analyze how the state is lived, in very real terms, in the fabric of everyday village life in the southeast, focusing on the period since the advent of GAP large-scale damming and water diversions, and highlighting the experience of the Harran plain in particular. As I discuss in the later sections, ways that villagers narrate these changes sheds light on how the Turkish state is experienced, and lived, but also necessarily exposes ways that rural residents situate themselves as part of, or in opposition to, larger economies and communities atregional or global scales (cf. Appadurai 1996), including in relation to the Turkish state and nation.

With respect to broader concerns related to the state, nation-building, the Kurdish question, or contemporary change in Turkey, specific contributions of this analysis include 1) theoretical contributions in terms of specifying the value of reading statesociety relations ethnographically, and in particular, through a reading that seeks to understand state-society encounters at the margins -in those liminal spaces where state practices are less apparent, or may be actively contested. This contribution enriches approaches to the contemporary state, and responds to calls for qualitative analyses of nation-building (Berger 2006) and for treatments of state practices and national identity that take seriously negotiations of socio-spatial difference (cf. Radcliffe \& Westwood 1996; Craske 2005). 2) Empirical contributions in terms of providing analysis of ways that residents of southeastern Turkey narrate and respond to Turkish state practices. While there is a rich literature on the Kurdish question generally, or with respect to GAP related development, there is very little that provides analysis of state-society encounters with attention to narratives and responses of residents living and working the region. As such, by elaborating the ways that the state is experienced, lived, and narrated in the southeast, this analysis adds significantly to literatures on Turkish state and nation-building (e.g. Secor 2007; Kaplan 2006), on Kurdish identity and historiography (e.g. Hirschler 2001; Yeğen 1996; Sömer 2004), to socio-political considerations related to the Southeastern Anatolia project (e.g. Harris 2002; Çarkoğlu \& Eder 1998; Öktem 2005; Erhan 1997) or geopolitical considerations related to the Kurds or the southeast (e.g. Harris 2008a; Gunter 2004; Ergil 2000; Erhan 1997). Furthermore, 3) the paper is not only of significance spatially (in the rural, ethnically diverse spaces of Turkey's southeast), but also temporally -through focus on changes underway as part of widespread irrigation delivery and other state-fostered changes associated with the GAP project. Finally, 4) as I elaborate in the concluding section, the analysis is suggestive not only of the changing horizontal and vertical reach of the state, but also of shifts in the ways that residents in the region understand themselves in relation to broader notions of community. Along these lines, it is 
suggested that contemporary state-led change in the southeast is likely to hold symbolic importance precisely given the history of conflictual relations, and specific discourse related to exclusion of the region invoked in Kurdish separatist discourse. As such, the analysis holds promise with respect to broader questions of citizenship, democratization, and changing citizen subjectivities.

With respect to method, the examination here draws from field-work conducted in the Harran plain, the first area to receive irrigation water through GAP. The plain is located directly north of the border with Syria (see Map 2) and is home to Arabic and Kurdish speaking minority populations, ${ }^{7}$ making it both a literal and figurative border of the reach and extent of Turkish language, ethnicity, and state influence. Narratives are drawn from interviews with state agents associated with the GAP program, both in Ankara and şanliurfa, as well as over sixty open-ended interviews conducted in the newly irrigated Harran plain and elsewhere in Southeastern Anatolia in 2001, 2004, 2005 , and 2007. A survey of 124 rural households in eleven different villages of the plain was also carried out cooperatively with a sociologist from Harran University in $2001 .^{8}$ Admittedly, results from the Harran plain must not be understood as representative for the entire southeast region, as experiences here necessarily differ from those of other populations and spaces of the region (particularly given that the plain is dominated by Arabic speakers, and populations here face issues very different from those of the Kurdish-dominated spaces to the north and east, particularly sites such as Diyarbakir, or small mountain villages that have been the primary sites of conflict over the past several decades). In particular, it must be born in mind that the Harran plain stands out politically from the rest of the southeast region, as an Arabic speaking pocket with distinctive regional political trends (i.e. that shuns pro-Kurdish politics that might be popular elsewhere in the region and with tendencies to favor Islamic and even Turkish nationalist political parties). Nonetheless, I ask: While the Turkish state has been analyzed ethnographically in the centers of Ankara or Istanbul (see Navaro-Yashin 2002; Secor 2007), or within specificstateinstitutions, ${ }^{9}$ what is the reach, extent, and constitution of the 'state' at its margins -in the impoverished, Arabic and Kurdish speaking, rural southeast? Furthermore, how are state-society relations evolving in the contemporary moment, particularly with regard to irrigation and other recent GAPrelated efforts? 
MAP 2: Recent Irrigation Projects in Southeastern Turkey: Harran Plain

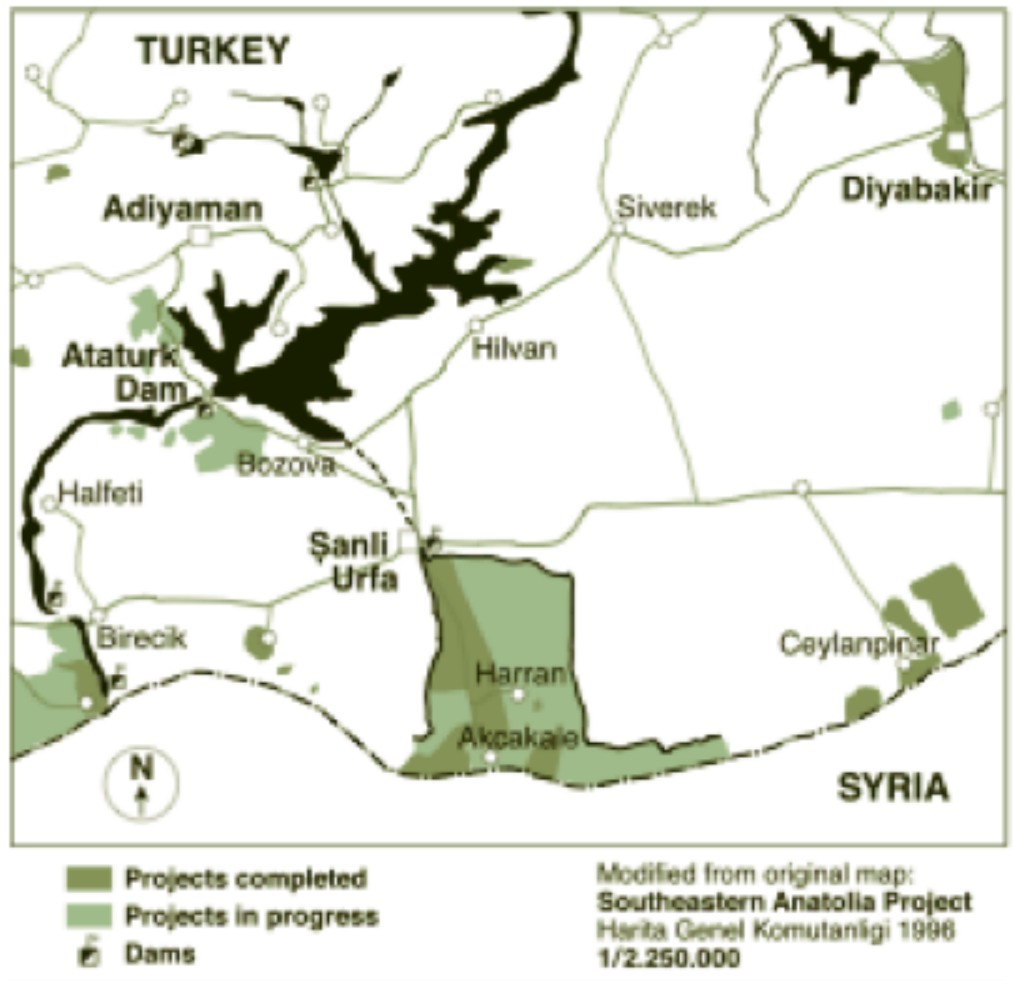

\section{Situating state-society relations in a Border Region}

With even a cursory understanding of Turkish history and politics, the salience of the southeast, and specifically the rural southeast, as an 'extreme' site to investigate the Turkish state should be clear. In brief, it can be argued that Turkish modernist aspirations, concerns over territorial integrity, and efforts to gain access to the European Union highlight the southeast region as a central space that is the locus of these interrelated issues (Harris 2008a). Perhaps with the exception of border disputes with neighboring Greece over Cyprus and the Aegean sea, the southeastern border with neighboring Syria and Iraq is a primary cause of disquiet for those concerned with solidifying and maintaining the borders and integrity of the 'Turkish state.' As the only majority Kurdish administrative region in contemporary Turkey, southeastern Anatolia has been the primary site of the decades-long conflict related to Kurdish separatism one of the most direct oppositions to Turkish state legitimacy and territory in the history of the Republic (see Kirşçi \& Winrow 1997; Watts 2007; Harris 2002; Dahlman 2002). More recently, the southeast has also been a focal point for rising Islamisms, a contentious staging ground for US-led attacks against neighboring Iraq, the site of continuing skirmishes between Turkish military and separatist forces, and a region that experiences frequent charges of state corruption and human rights abuses. All of these issues make the southeast of particular importance for Turkish state and nationbuilding, also serving as a locus of concerns frequently highlighted with respect to European concerns about possibilities for Turkish accession to the EU (see also Gunter 2004; Ergil 2000). 
11 I highlight the importance of the southeast together with other scholars who argue that there is theoretical significance to studying states and nations at their metaphorical and literal 'borders' (see Jones 2009; Paasi 2005 and other authors for recent examples of the growing interest in border studies). As Kaplan et al. assert with respect to nationalism (1999), there is a lot to be learned by considering borders, those sites which are simultaneously both 'inside' and 'outside' the nation, revealing precisely how it is that nation-building processes come undone (or, are also maintained and consolidated)..$^{10}$ Referring to 'border' sites as transgressions that disrupt the very idea of the nation-state, these authors write, 'in attempting to consolidate its nationalist power for the well-being of the people, thenation-state often overlooks the effects its decisions and consequent events may have on diverse populations whose difference, often marked through concepts such as sexuality, gender, race, ethnicity, and class, may situate them adversely to a center' (Kaplan et al. 1999: 5). Focusing on the 'border' of the GAP region similarly highlights the betweenness, indeterminacy, and double-movements of the Turkish nation and state, simultaneously writing these peoples and spaces as outside of Turkey, and attempting to incorporate them more fully into Turkish economies, politics, and identities (see also Radcliffe \& Westwood 1996; Craske 2005; Zurcher 2005 for analyses of nationalism attentive to socio-spatial difference).

Consideration of contemporary state interactions and bordering processes in the southeast necessarily requires some attention to the history of these issues. While the map of contemporary Turkey was officially drawn in $1923,{ }^{11}$ it wasn't until the $1940 \mathrm{~s}$ and 1950s that the southeastern borders between Turkey and its neighbors were solidified with the arrival of state agents to police the territorial limit of the Republic. Prior to that time, residents of the region would pass across the plains into present-day Syria without concern for official passports, state agents, or internationally recognized maps of what constituted 'Turkey'. As Yeğen (1996) has described, the solidification of the border in southeastern Turkey served to cut off traditional trading routes including those that had long been established between Kurdish areas in Turkey and those farther to the south and east..$^{12}$ In this sense, efforts to create a 'Turkish economic space' proceeded by marginalizing traditional economic relations and possibilities. In a similar fashion, the solidification of the official borders between the states cut off transhumance routes of nomadic pastoralists who had traditionally summered in the high mountains of eastern Turkey and wintered in the plains of Syria. Indeed, many villages of Turkey's Harran plain were only established after the formal creation of the border between Turkey and Syria. With the formal establishment of the border, nomadic populations were systematically settled and animal husbandry livelihoods gave way to settled agriculture. ${ }^{13}$

13 The relatively recent solidification of the international border is an important issue to highlight, both to emphasize state attempts to consolidate the mapped territory of Turkey as distinct from that of its neighbors and to indicate the consequences the extension of the Turkish state apparatus throughout the border areas has had for residents of the southeast.

14 Throughout Turkish historiography, there has been a great deal of emphasis placed on demarcating Turkey from its 'Arab' neighbors, specifically following the dismantling of the Ottoman Empire. As described by Navaro-Yashin (2002: 49) 'no affinity between Turkish and Arab cultures of the Middle East was allowed in official accounts of 
geography and history,' instead a cultural border between Turkey and the Arab world was constructed and policed. For instance, schoolbooks were very careful to separate 'Turks' from 'Arabs.' As she explains, much of this insistence resulted from portrayals of Arabs as having threatened the integrity of Ottoman rule. Rising Arab nationalisms explicitly challenged the Islamic Caliphate under the sultan, resulting in portrayals of Arabs as those who betrayed their Ottoman brothers. Such discourses continue to this day, deliberately writing the Arab world as outside of and even oppositional to Turkey or Turkishness, with implications for Turkey's contemporary regional geopolitical affiliations (witness current efforts to gain entry to the European Union or hostilities between Turkey and Iraq or Syria of the past several decades).

Consideration of these nationalist discourses is important to situate the ways that contemporary residents in my study area may understand themselves in relation to the state. As an isolated 'Arab' pocket within Turkish territory the Harran plain is a critical, and problematic, target of contemporary state interest and intervention with irrigation delivery and the GAP project. With 80-90 percent of the Harran plain as Arabic speaking, the plain extends the Arab populations from Syria into Turkish territory, creating an ethnically and linguistically minority Arab population.The plain is thus both the literal border area between Turkey and its Arab neighbors to the south, and also a site that disrupts those very distinctions, instead demarcating the existence of 'Turkish Arabs' within Turkish territory. Thus, the insistence that Turks are distinct from Arabs that has been so foundational to Turkish nationalist discourses exposes attempts to fix the territorial mapping of Turkey to fundamental challenge, as these populations are claimed simultaneously as both within and without 'Turkey' (cf. Kaplan et al. 1999). Thus, within the broader context and importance of the southeast as a Kurdish site, the peculiar geography of the Harran plain is also important to expose the limits and tensions inherent to Turkish state and nation-building projects. Attempts to solidify and fix the border, and to extend the reach of the Turkish state throughout the southeast, necessarily exposes tensions, fissures, and ambivalences inherent in such a project (Harris 2008a). ${ }^{14}$

16 Before turning to contemporary illustrations of changing state-society relations in this region, it is also necessary to briefly mention other aspects of state-society interactions in the rural spaces of the southeast, as well as to provide some general context on socio-economic considerations in the region and for the Harran plain. ${ }^{15}$ In the early days of the Republic, the Turkish state first demonstrated interest in Anatolian village life by sending agents to villages in order to discover 'authentic' Turkish language and culture. Over the past several decades, many would characterize the predominant focus of state-society interactions as militaristic, dominated by the Kurdish conflict, the state's burning and evacuation of villages, limits on assembly and cultural-linguistic expression, and state-imposed curfew (see Yavuz 2001; White 2001; Mutlu 2001; Kirşçi \& Winrow 1997 for more detail on the Kurdish issue and for understanding of ways in which this has been a predominant feature of all state-society questions for the region, and even for Turkey on the whole). In terms of state-led developmentalism, recent state interest in the area has included electricity delivery, drinking water provision, and more recent interventions related to irrigation, health, and agriculture associated with the large-scale Southeastern Anatolia Project (GAP) (see Ünver 1997a, 1997b; Carkoğlu \& Eder 1998; Erhan 1997; Harris 2002; Akşit 1996, for overviews of the GAP region, the GAP project, and related socio-cultural considerations). While the bulk of the research discussed in this article focuses on irrigation and other GAP-related 
interventions, many villagers in the Harran plain invoke the coming of electricity as an initial state intervention of great import. They attest that it has only been since the recent delivery of electricity that the state has extended its reach and concern to include their villages. As such, narratives related to electricity suggest that this made villagers feel as though they were not entirely forgotten by the state, implicitly suggesting as well that prior to the 1970s and 1980s, these villagers felt themselves to be 'outside' of state interest and concern. Stronger connections to the Turkish state in these village spaces were further solidified with the ensuing arrival of television and telephones throughout the region. Whether watching news of the Turkish parliament, learning the Turkish language through TV, encountering state agricultural extension agents on GAP TV, ${ }^{16}$ or maintaining telephone contact with sons in the military, the contact zones between the state and rural residents have clearly been extended and intensified over the past several decades. The empirical material presented below must necessarily be understood in relation to these long-standing state interventions in these rural areas, ${ }^{17}$ as well as in relation to the ongoing discourses of exclusion and difference that mark the region as Arab, Kurdish, underdeveloped, or a modern (again, see Harris 2008a).

Part of my argument is that the recent establishment of canalet irrigation up to the border, but not beyond, is an important recent intervention that marks the boundary of what lies 'within' and 'without' modern Turkey, and serves as a recent chapter in the complex and evolving history of state-society relations in this contested region. Turkish state agents are again traveling to small Anatolian villages, this time not to rediscover an authentic Turkish past, but to forge a modern Turkish future. The coming of irrigation to the Harran plain required a flurry of activity to prepare the fields and villagers for what was to come; state agents from DSi (State Hydraulic Works) built the canalets, Village Services and other agencies built roads and began ongoing processes of land leveling and drainage works, scientists and engineers took measurements and conducted research, drinking wells were established, and preliminary steps were made to create new management mechanisms in the form of Water User Groups to maintain the irrigation infrastructure. To prepare for water delivery in the plain, state agents redistributed agricultural plots as part of a land consolidation program to make the size and shape of the plots more suitable for irrigation. As with the introductory vignettes, I now turn to ways that villagers in the region narrate irrigation and other recent changes, and what this suggests in terms of intensified state presence in the daily lives and practices of villagers in the Harran plain, and in turn, what this might suggest in terms of tracing ever-shifting statesociety relations in these marginal and contested rural spaces.

\section{Recent Engagements: Shifting State-Society relations with Irrigation Delivery to the Harran Plain}

18 Narratives offered by villagers in the Harran plain invoke the 'state' in relation to everything from crop selection (for instance due to cotton subsidies) to increased marginalization of those engaged in animal husbandry (a process that began long ago with Ottoman and Turkish state sedentarization of nomadic pastoralists). These recent state irrigation-related interventions in village life -to measure salinity levels, monitor water usage, test soil quality, or to teach appropriate irrigation techniques- augment 
and intensify long-standing state presence in these rural spaces. With these changes, it is important to consider how villagers narrate the 'state' in relation to these changes, including their sense of themselves in relation to state agents, interests, and practices.

While interviewing rural residents about irrigation-related changes, villagers often stressed that state interest in the region has changed. For instance, respondents remarked 'at least the state turned its face towards us', or 'the state thinks about us now'. Another said, 'We did not see any accomplishments of governments in the past, we are a little bit happy to see some now'. In relaying such sentiments, several credited recent state attention to the southeast directly to the late leader Turgut Özal. ${ }^{18}$ One such response was provided by Sübyan, a man who now works as an irrigation technician and who lives in an Arabic speaking village in the central part of the plain. ' Sulama [irrigation] has been good. Water brought life here. Özal knows the people of this region and knew that 90 percent of the 1 million people living here used to go work as seasonal workers, he initiated the project andTansu Çiller brought the water. Nobody leaves here as seasonal workers now, people in fact come here to work'.

By linking state leaders Özal and Çiller to irrigation and related changes in his village, Sübyan answers a question related to irrigation with a commentary on the 'state', discursively connecting the irrigated landscape and economy to state actors and interests. In some senses this is intuitive, as the state is the instigator of irrigation and advertises all that it is doing for villagers through GAP TV and other means. In another sense, this connection is striking. Sübyan is providing a reading of the state, and also state legitimacy, in relation to the changing agro-economy of his village. In so doing, he allies himself with a larger group of residents who appear to welcome increased attention and intervention of the 'state' in village life. Characterizing himself and his village as 'beneficiaries' of Özal's vision and Çiller's implementation, such statements pose fundamental challenges to simplistic accounts that portray rural residents of the southeast, or ethnic minorities in particular, as oppositional to encroachments of the state or modernization efforts -an issue I revisit in the conclusion. ${ }^{19}$

The most common response of villagers of the Harran plain to the question of 'why did the state bring irrigation to your village?' in our 2001 survey was 'to benefit the farmers', 'to benefit the village', 'to benefit us', or some variation. Of 125 respondents, approximately $76(60 \%)$ noted in their answer that it was in part to benefit the people or villages of the plain. A proportion of respondents (approximately 30 of 125 , or $24 \%$ ), noted that the state intends to benefit rural residents, but also 'itself.' ${ }^{20}$ As explained by one villager, the state brought irrigation to the village 'to have the land worked on, to benefit the state and the people in the region'. Another young woman noted, 'First, the villagers here will gain and then the government will gain. The government is charging for the water and also getting taxes'. Particular reasons that villagers noted to describe how the state is likely to also benefit from irrigation include: to develop the region economically, to generate taxes from increased income, increased productivity (as the state is the major purchaser of cotton), and from the collection of irrigation fees (which is arguable as irrigation water remains heavily subsidized, in 2001 priced at approximately $\$ 4$ per decare of cotton for an entire season of unlimited water). Others note additional reasons for delivering irrigation: to reduce unemployment, to induce farmers to grow cotton, to benefit the landowners, to develop the region and stop migration to urban areas, this is a reason also cited in GAP planning documents), and one even noted that state delivery of irrigation is 'for God'. 

beneficial, at times noting 'benefits' also for the state, a smaller subset (approximately $10 \%$ of respondents) conveyed negative or skeptical understandings of state irrigation delivery. Negative responses were more likely among those who had been animal herders prior to canalet irrigation delivery, among the landless, and among women (Harris 2008b), ${ }^{21}$ indicating that there are some important differences related to experiences of these changes among residents of the plain, and among those living in the southeast region more generally (see also Harris 2006 for discussion of socio-spatial difference related to GAP changes). Among more negative respondents, one villager repeated back the question to introduce his skeptical response "why did the state bring you water?... The state brought irrigation to its own lands, the state didn't bring water to us. We are hand laborers for the state, did they bring it for us? [bize mi getirdi?]'. Another complained, 'the country is rich, but the people are poor because the state keeps eating all the money', referring to corruption and inequality, and echoing concerns of other villagers who noted that state agents involved in GAP took bribes for certain jobs or for land distribution. Paralleling dissatisfaction with state practices among some villagers, several GAP-affiliated employees also complained about the 'state' as overly bureaucratic to the extent that investors pull out of the region, or as failing to give needed levels of support for engineers and other agents to do their job.

23 Following the question of 'why did the state bring irrigation to your village?' we asked directly whether or not the delivery of irrigation has changed respondents' attitudes towards the state. ${ }^{22}$ Again, responses varied, but generally villagers conveyed increasingly positive associations with the state. 'We now have a more positive attitude towards the state because we used to go to places like Adana, but now we are working on our fields directly in front of our houses'. ${ }^{23}$ Another noted, our view of the state 'changed positively': 'We had hatred before but now they started investing in the southeast. The state started to think of us'. Similarly, 'My positive feelings increased because we now have electricity, water and are more comfortable'; 'We did not trust the state before. But it brought electricity, water, phone etc. to us and now we trust the state a lot'; or even more forcefully: 'since the state cares for us, we have become more devoted to the state'. Another said it this way: 'the head of the household is more appreciated if he takes care of his family, we have come to appreciate the state more'.

For these residents, receiving renewed state attention and services has resulted in an intensified sense of belonging and loyalty as citizen subjects. The characterization of the state as family by referring to the 'head of household' is especially notable, drawing directly on a notion of the state as a patriarchal unit (as with the term devlet baba [father state]) obligated to care for those under his charge and directly linking state irrigation delivery to nation-building. Such associations have obvious implications for questions of state legitimacy, related questions of support for Kurdish separatism in the region, as well as Benedict Anderson's (1983) question of how people forcefully identify with a 'nation' to the extent that they are willing to offer their lives in its defense. To varying degrees, all of these positive responses convey citizens' intensified relationships with the state, either perceiving themselves increasingly as under the charge of the state, situating themselves as increasingly 'devoted' to the state, or as beneficiaries of state services. For some of these villagers, irrigation delivery is clearly creating a field for intensified nationalist association and state consolidation, enabling 
consideration of how it is that states are established and maintained overtime through specific practices.

While such positive characterizations of the state following irrigation delivery were common, a smaller proportion of respondents noted increasingly or persistently negative perceptions of the state. Among the more skeptical responses, one noted: 'My ideas about the state changed, but not in a positive way -I wish land reform was carried out'. Another said, 'Nothing changed for me but those who are rich became richer'. Echoing these concerns, another said: 'It changed negatively, because only the landowners benefited from irrigation. The rich are richer, the poor became poorer'. Similarly highlighting inequalities as a lens through which to understand the state, yet another said: 'It brought an increase in welfare of the people. But it did not benefit everyone because those who did not have land were kept down as workers'. For these villagers, the differential benefits of irrigation have highlighted and even exacerbated inequalities in the region, intensifying concern with respect to landholding differentials and heightening dissatisfaction with the state. Other responses similarly noted the uneven benefits associated with irrigation, 'the state didn't benefit me by bringing water, only the landlord'. A 29 year-old Kurdish man said it this way: 'Supposedly, the state brought water for improvement of people -to create better economic conditions- but it divided people (into classes). I developed negative feelings about the state. It has double standards'. As these portrayals suggest, perceptions of irrigation-related changes vary importantly with respect to landholdings, livelihoods, and other factors. ${ }^{24}$ The variability of experiences of irrigation conveyed by this diversity of portrayals reflects the 'situated knowledges' of residents (Haraway 1991), demonstrating how landholding or livelihood situations inflect varied perceptions and understandings of the state.

Interestingly, common to all the portrayals, whether positive or negatively inclined, is the recognition of the state itself as the purveyor of these changes, and by extension, the state itself as an object of interest and concern (cf. Mitchell 1991, as detailed more fully in Harris, in process). It is also of interest to note that many of the negative portrayals do not cast irrigation itself negatively, but instead perceive state failures with respect to ensuring that the benefits of irrigation are shared equitably or to ensure that the benefits will last well into the future (see Harris 2009). For these farmers, they may not be opposed to irrigated agriculture, but would only prefer that more attention be paid to make sure that they too enjoy the benefits associated with these changes. Among the more negative portrayals that cast irrigation as altogether detrimental, Amit's quote prefacing this article names GAP as a 'suicide pill' for animal herders. Others invoked the term 'slavery' to express their situation as sharecroppers falling increasingly in debt. For others, new visible markers of wealth among the landed, with increasing numbers of cell phones and cars, have made them feel relatively worse off, heightening a sense of division between the rich and poor, as one woman said, 'we have been left more backward'. These views were a minority in terms of frequency of responses, but nonetheless portrayed profound senses of exclusion from irrigation economies and, by extension, the Turkish nation and state (again, see analysis in Harris 2009 and 2008b for discussion of overall positive associations with irrigated agriculture, as well as differentiated experiences of these changes among different populations of the region). 
Some respondents also took the opportunity to call the state to task for perceived failures in meeting obligations to rural residents in other senses. Referring to the fact that after irrigation delivery they were expelled from land they rented for twenty-five years, one rural resident said, 'we call the state to do its job...we want the state to work for citizens'. Another woman noted, 'We want the state to be more interested in the region, we feel sadness for being forgotten'. By intervening in village lives and economies, the transition to irrigation has thus also exposed the state to new types of critique. Most often, the failure of the state to enable the full realization of irrigation's potential is noted, 'because the state couldn't organize the irrigation fairly therefore my feelings/thoughts remained the same'. Others echoed the sentiment with respect to the need for land reform, 'now we want real land reform'. ${ }^{25}$ One 25 year old Arabic speaking woman said it this way: 'We are unhappy with the system, the government, their coming and going. We want peace, equality, and most importantly, for the work done by poor people to be valued'. For her, state irrigation delivery is insignificant as long as there are other more substantive problems, making recent efforts appear feeble in the absence of more widespread reform. For these residents and others as noted, state irrigation delivery highlights other aspects of services that have not yet been dealt with, opening the state up to critique as residents sense that they can legitimately raise further, or more long-standing, demands. Even as such statements suggest that the state has not yet performed its duties adequately, these narratives are nonetheless suggestive of a sense of citizenship among these residents. They are, in part, expressing that they view themselves as citizen-subjects -able to call on the state to meet its obligations to them.

\section{Conclusions: Reconsidering State-Society relations in a Contested Border Region}

Given the histories of state repression and conflict in the southeast, it is fair to say that I was expecting much more negativity and distrust towards the 'state' than I found. Even with some overtly negative and critical responses, the general impression I was left with after more than 60 open-ended interviews and 124 survey responses is that many consider that while they had not been well-served by the state previously, they are receptive to recent development efforts in many senses and consider these interventions to be long overdue. Despite several possible issues that might have resulted in some respondents painting a more favorable impression of the state than they otherwise might, ${ }^{26}$ the overall positive association with irrigation and state intervention in this contested border region nonetheless presents a puzzle, particularly as other commentators have argued GAP related changes have aggravated volatility in the region (e.g. Öktem 2005). This issue of receptivity towards the state is also borne out by earlier research, for instance the survey conducted by Akşit and Akçay in soon to be irrigated areas (conducted in 1993, published in 1997). While there are remarkable differences between the 1993 results and our own from 2001, both demonstrate a strong receptivity on the part of rural residents to enhanced state involvement with respect to water management.Consider for instance, results from the 1993 survey related to the question 'Who should own the water?' To this question, $66 \%$ of respondents said 'God', $27.5 \%$ said 'the state', $3.8 \%$ said 'the user', and $2.5 \%$ said 'society'. When asked 'who should control the water?' $80 \%$ said 'the state', and the other 
$20 \%$ felt management should be left to the farmers themselves. We repeated these two questions in our 2001 survey of recently irrigated areas of the Harran plain. We asked, 'According to you, who should own the water?'. The responses received were 59\% of respondents said 'the state', $15 \%$ said 'the farmers' and $14 \%$ said 'water user groups'. Not a single respondent said 'God' in our survey, while this was the majority response in the Akşit and Akçay survey, 66\% (during open ended interviews, however, 'God' was mentioned on several occasions in response to similar questions). ${ }^{27}$ To the question of 'who should manage the water?' the majority of respondents in the 2001 survey said 'the state' (48\%), while a lesser number said 'Water User group' (36\%), and only 5 respondents said 'farmers' (6\%). Regardless of difficulties in comparing the results of these surveys, it is interesting that for both there are the relatively few respondents who note that water ownership and management should be in the hands of the farmers themselves; instead, the 'state' is perceived as most legitimate in terms of water ownership and control.

I consider such favorable responses to be significant, especially given the contentious nature of contemporary debates related to Islamism/secularism, Kurdish cultural rights, or tensions related to exclusions of 'Arabs' within Turkey, all of which are particularly salient throughout the southeast. ${ }^{28}$ Indeed, it is possible that residents of the region are receptive to the Turkish state's attention to the region precisely because the lack of state investment historically has been a primary discourse that the Kurdistan Workers Party (PKK) has invoked to garner support for the separatist movement (see Mutlu 2001). Given this, the discourse regarding the southeast as having been left out of state interest and attention is a familiar one, and undoubtedly frames the ways that villagers narrate state intervention in their villages as present. This might provide a partial answer for why state intervention may be viewed as welcome in this 'forgotten' region (Harris 2008a, 2008b). This possibility points to the potential that GAP-related changes hold a great deal of symbolic importance, also with considerable possibilities for recasting state-society relations in this contested border region.

While I have argued that the state is productively analyzed through narrations of villagers living in the marginal spaces of the rural southeast, it is also worthwhile to reemphasize that, at once, with such invocations of the 'state', villagers are also recasting and articulating themselves as subjects of nationalist, statist, and modernization efforts. Indeed, as Sömer (2004) has also argued it is important to consider ways that identities and notions of Kurdishness and Turkishness are cast as compatible, and may shift over time, in relation to state discourse and policy, rather than viewing such identities as static. Similarly, he also calls for more work that considers the Kurdish question not in relation to cultural rights, or security threat, but through focus on self conception and political beliefs of Kurds themselves, including how these are being continually reshaped through development processes in particular. In case study work described here, there is considerable evidence through which to consider how elements of statist and nationalist projects take hold among rural residents, and similarly, how notions of Turkishness, Arabness, or Kurdishness may be reimagined and recast in relation to ongoing state-society shifts. As such, we can begin to consider how Kurds, Arabs, and others that have been historically marginal to Turkish state and nation-building are reimagining themselves, and their relationship to the state, in the contemporary moment: 'We are Turkish citizens but the state exploits us', or 'the state thinks about the villager' or 'I don't think the state 
profits from sulama[irrigation]. The state did land leveling for us. The state thinks about its citizens'. All such statements simultaneously assess the 'state', and also position rural residents as 'citizens', or even as beneficiaries in relation to such endeavors. In such examples, even when the 'state' is characterized in a negative sense, for instance, as exploitative, the respondent nevertheless views himself as 'a citizen of the 'Turkish' state'. Again, such associations are significant, especially when we consider the histories of difference that have persistently marked the region economically, culturally, and linguistically. These results can also be read as significant given broader globalization-related processes underway, as the possibility of intensified associations with national or state scales necessarily proceed in tension with increasing focus on supranational, global, or even local scales that are gaining force in the institutional and governance realms (cf. Appadurai 1996; Agrawal 2005). Along these lines, these results are also interesting in light of claims made that people's associations with the nation or state within which they reside has become increasingly tenuous in a globalized era as citizens are increasingly connected to other peoples and places beyond the state's borders, making the ideal of state borders that match up with social boundaries as increasingly elusive (Migdal 2004).

31 For rural residents to recognize themselves as Turkish, as recipients of state services, or, in the case of the one quotation above, as part of a family being cared for by the state provides testimony to the success (even if limited) of Turkish state and nationbuilding efforts. Within the terms of a Turkish state-building project not yet a century old, irrigation is the latest iteration of practices that further extend the Turkish state and nation into border regions that have long been contested, and have consistently foiled attempts to simplistically mark the territory and populations as singularly 'Turkish.' All of this suggests the need to move beyond simplistic associations of the southeast as 'Kurdish' or necessarily oppositional to the Turkish state. Instead, we need to consider the co-constitution of Turkish, Kurdish, and Arab citizen subjects, and indeed, the ways that the Turkish 'state' and 'nation' themselves are iteratively produced, and refashioned in relation to ongoing changes and negotiations.

\section{BIBLIOGRAPHIE}

Agrawal, Arun (2005) Environmentality: Technologies of Government and the Making of Subjects contd., Durham \& London, Duke University Press.

Akşit, Bahattin; Akçay, Adnan (1997) 'Sociocultural Aspects of Irrigation Practices in Southeastern Turkey', Water Resources Development 13(4), pp. 523-540.

Akşit, Bahattin (1996) 'Population Movements in Southeastern Anatolia: Some findings of an empirical research in 1993', New Perspectives on Turkey 14, pp. 53-74.

Anderson, Benedict (1983) Imagined Communities: Reflections on the Origin and Spread of Nationalism, London, Verso. 
Appadurai, Arjun (1996) Modernity at Large: Cultural Dimensions of Globalization, Minneapolis, MN, University of Minnesota Press.

Ataman, Muhittin (2002) 'Ozal Leadership and Restructuring of Turkish Ethnic Policy in the 1980', Middle Eastern Studies 38(4), pp. 123-142.

Berger, Mark (2006) 'From Nation-building to State-building: the Geopolitics of Develpoment, the Nation-state System and the Changing Global Order', Third World Quarterly 27(1), pp. 5-25.

Çetin, Sinan ; Çetin, Cemil (1999) Propaganda. A Plato film production, International Sales, Warner Bros, Istanbul, $116 \mathrm{~min}$.

Çarkoglu, Ali; Eder, Mine (1998) 'The Southeast Anatolia Development Project', CIDCInsight: Turkey No. 18 (July), pp. 111-123.

Craske, Nikki (2005) 'Ambiguities and Ambivalences in Making the Nation: Women and Politics in 20th century Mexico', Feminist Review 79, pp. 116 -133.

Dahlman, Carl (2002) 'The Political Geography of Kurdistan', Eurasian Geography and Economics 43(4), pp. 271-299.

Erhan, Selahattin (1997) 'The Social Structure in the GAP Region and Its Evolution', Water Resources Development 13(4), pp. 505- 522.

Ergil, Doğu (2000) 'Identity Crises and Political Instability in Turkey’, Journal of International Affairs 54(1), p. 43.

Gupta, Akhil (1995) 'Blurred Boundaries: the Discourse of Corruption, the Culture of Politics, and the Imagined State', American Ethnologist, May. 22(2), pp. 375-402.

Gunter, Michael (2004) ‘The Kurdish Question in Perspective’, World Affairs 166(4), pp. 197-205.

Haraway, Donna (1991) 'Situated Knowledges: The Science Question in Feminism and the Privilege of Partial Perspective' in Simians, Cyborgs, and Women: The Reinvention of Nature, New York, Routledge, pp. 183-201.

Harris, Leila in process.

Harris, Leila (2009) 'Contested Sustainabilities: Assessing Narratives of Environmental Change in Southeastern Turkey’, Local Environment 14(8), pp. 699-720.

Harris, Leila (2008) 'Modernizing the Nation: Postcolonialism, (Post)Development, and Ambivalent Spaces of Difference in Southeastern Turkey', Geoforum 39 (5), pp. 1698-1708.

Harris, Leila (2008) 'Water Rich, Resource Poor: Intersections of Gender, Poverty and Vulnerability in Newly Irrigated Areas of Southeastern Turkey', World Development 36(12), pp. 2643-2662.

Harris, Leila (2006) 'Irrigation, Gender, and Social Geographies of Waterscape Evolution in Southeastern Turkey', Environment and Planning D: Society and Space 24(2), pp. 187-213.

Harris, Leila (2002) 'Water and Conflict Geographies of the Southeastern Anatolia Project', Society and Natural Resources 15, pp. 743-759.

Hirschler, Konrad (2001) 'Defining the Nation: Kurdish Historiography in Turkey in the 1990s', Middle Eastern Studies 37(3), pp. 145-166.

Jones, Reece (2009) 'Categories, Borders, and Boundaries', Progress in Human Geography 33, p. 174.

Kaplan, Caren; Alarcon, Norma; Moallem, Minoo (eds) (1999) Between Woman and Nation: Nationalisms, Transnational Feminisms and the State, Durham, Duke University Press. 
Kaplan, Sam (2006) The Pedagogical State: Education and the politics of national culture in post-1980 Turkey, Stanford, CA, Stanford University Press.

Kirişçi, Kemal; Winrow, Gareth Winrow (1997) The Kurdish Question and Turkey: An Example of Trans-state Ethnic Conflict, London, Frank Cass.

Migdal, Joel (2001) State in Society: Studying how states and societies transform and constitute one another, Cambridge, Cambridge University Press.

Migdal, Joel (2004) 'State Building and the Non-Nation-State', Journal of International Affairs 58(1), pp. 17-46.

Mitchell, Timothy (1991) 'The Limits of the State: Beyond Statist Approaches and their Critics', American Political Science Review, March 85, pp. 77-96.

Moore, Donald (1993) ‘Contesting Terrain in Zimbabwe's Eastern Highlands: Political Ecology, Ethnography, and Peasant Resource Struggles', Economic Geography, October 69(4), pp. 380-401.

Mutlu, Server (2001) 'Economic Bases of Ethnic Separatism in Turkey: An Evaluation of Claims and Counterclaims', Middle Eastern Studies 37(4), pp. 101-135.

Navaro-Yashin, Yael (2002) Faces of the State: Secularism and Public Life in Turkey, Princeton University Press, Princeton.

Öktem, Kerem (2005) Reconstructing Geographies of Nationalism: Nation, Space, and Discourse in Twentieth Century Turkey, unpublished PhD Thesis, School of Geography and Environment, Oxford, UK, University of Oxford.

Paasi, Anssi (2005) 'The Changing Discourses on Political Boundaries: Mapping the Backgrounds, Contexts, and Contents' in Van Houtum, Henk; et. al. (eds) B/ordering Space, Aldershot, Ashgate.

Radcliffe, Sarah; Westwood, Sallie (1996) Remaking the Nation: Place, identity and politics in Latin America, London, Routledge.

Secor, Anna (2007) ‘Between Longing and Despair: State, Space, and Subjectivity in Turkey’, Environment and Planning D: Society and Space 25, pp. 33-52.

Shankland, David (1999) 'Integrating the Rural: Gellner and the Study of Anatolia', Middle Eastern Studies 35(2), pp. 132-149.

Sömer, Murat (2004) ‘Turkey’s Kurdish Conflict: Changing Context, and Domestic and Regional Implications', Middle East Journal 58(2), pp. 235-253.

Strayer, Joseph (1970) On the Medieval Origins of the Modern State, Princeton, Princeton University Press.

Ünver, Olcay (1997a) 'Southeastern Anatolia Integrated Development Project (GAP), Turkey: An Overview of Issues of Sustainability’, Water Resources Development 13(2), pp. 187-207.

Ünver, Olcay (1997b) ‘Southeastern Anatolia Project (GAP)', Water Resources Development 13(4), pp. 453-483.

Watts, Nicole (2007) 'Silence and Voice: Turkish Politics and Kurdish Resistance in the Mid $20^{\text {th }}$ Century', Ahmed, M.; Gunter, M. (eds) The Evolution of Kurdish Nationalism, Costa Mesa, CA, Mazda Press.

White, Paul J. (2001) Primitive Rebels or Revolutionary Modernizers? The Kurdish National Movement in Turkey, New York, Zed Books. 
Yavuz, Hakan M. (2001) 'Five Stages of the Construction of Kurdish Nationalism in Turkey', Nationalism and Ethnic Politics 7(3), pp. 1-24.

Yeğen, Mesut (1996) 'The Turkish State Discourse and Exclusion of Kurdish Identity in Turkey', in Kedourie, S. (ed) Identity, Democracy, Politics, London, Frank Cass, pp. 216-229.

Zurcher, Erik-Jan (2005) 'How Europeans adopted Anatolia and created Turkey', European Review 13(3), pp. 379-394.

\section{NOTES}

1. The author wishes to acknowledge tremendous research support from the University of Wisconsin-Madison, the University of Minnesota, and the American Research Institute in Turkey. Nurcan Atalan-Helicke also offered research support for the work presented here. Special thanks also to Nicole Watts, members of the EJTS editorial board, and several anonymous reviewers for comments on earlier versions of this manuscript.

2. One decare is equivalent of one-tenth of a hectare, or 0.2471 acres.

3. GAP is the Turkish acronym for the large-scale state development project Güneydoğu Anadolu Projesi or Southeastern Anatolia Project. The project is extensive, revolving around damming and diversion of the Tigris and Euphrates rivers to pursue 'integrated regional development' of Turkey's most impoverished region (see Ünver 1997a, 1997b for overview; Harris 2002 ; Öktem 2005 for critical analysis).

4. According to Ünver (1997a: 466), prior to irrigation, average family income in the plain was approximately $\$ 1,034$ in 1994 , and after irrigation delivery in 1995 , it rose to closer to $\$ 4000$. More recent estimates that take into accounts the effects of the 2001 financial crisis in Turkey are not available. See Harris (2008b) for discussion of other changes that accompanied this increase in average household income (including increasing expenses, increasing debt, and other related changes).

5. As Shankland (1999) argues, it is essential to attend to rural processes to appropriately understand questions of modernization and other socio-cultural dynamics of importance in contemporary Turkey. The analysis here contributes centrally to such a project.

6. As such, questions were asked directly about the 'state' (see footnote 15), but analysis also includes the ways that villagers invoked the state in relation to irrigation and GAP-related changes generally.

7. Estimates are that approximately $80 \%$ of residents in the plain are Arabic speaking and $20 \%$ Kurdish speaking. This refers to primary or familial language spoken, as residents generally also speak Turkish. It is problematic in some sense to use native language as a proxy for an understanding of 'ethnicity' (Akşit, 1996), and it is politically contestable to refer to individuals as either 'Arab' or 'Kurdish'. At times, I reproduce those designations in my analysis, however, due to the fact that villagers often describe themselves or others as such Arap or Kürt. Some villagers may, while identifying their family with either of these designations, also forcefully associate themselves as Türk. Thus, these categories should not be understood as singular or finite.

8. The survey was carried out in 11 different villages of the plain, representing approximately $10 \%$ of Harran plain villages, and selected according to location in the plain (with villages selected to provide geographic coverage of all regions of the plain), as well as also representing different irrigation union districts. Particular villages were selected based on size, from 300 to 800 residents (making these 'middle' sized villages), and primary language spoken (nine predominantly Arabic-speaking villages and two predominantly Kurdish speaking villages were chosen to maintain the $80 \%$ Arabic speaking ratio of the plain). Among survey respondents, 91 
were men and 33 were women. For in-depth interviews with villagers, there were approximately 30 male respondents and 30 female respondents. See Harris (2008b) for more in-depth analysis of survey results, particularly for discussion of differentiated experiences of irrigation among residents in the plain relative to gender, ethnicity and landholdings.

9. Much recent work on the micro-physics of state power and distributed effects of state practices following Foucault has tended to focus on institutions such as prisons or schools (see Kaplan 2006 for a study of state and nation with respect to the education system in Turkey). As Navaro-Yashin argues, in addition to studying such institutions, there is a need to also understand the ways that the state is invoked and maintained in relation to quotidian practices, whereby people enact, or critique the state in everyday senses.

10. In another paper, Harris 2008a, I argue that the southeast is also significant for understanding Turkish modernization efforts -as both a site of intense interest in overcoming underdevelopment and also as a site where certain key elements undermine modernization attempts.

11. With the exception of the Hatay province, annexed from Syria in 1938.

12. As described in detail by Yeğen (1996), the solidification of the border areas had important implications for economies and social interactions throughout the Kurdish areas in Turkey and surrounding countries. Specifically, as each new state attempted to attain integrated 'national economies' within its own national borders, traditional Kurdish traditional trading routes and spheres of interaction were fragmented. Economic circulation between Damascus, Baghdad, Aleppo and elsewhere were cut off to the extent that continued trade across trans-state Kurdish areas was even criminalized, branded as 'smuggling'. These processes were among many that led to economic disarticulation in the southeastern Anatolia region. More recent geopolitical tensions, including US-led wars in Iraq, have continued such processes, with many years of sanctions that again criminalized trade along routes that had been historically significant for Kurdish populations, including between Turkey's southeast and neighboring Iraq, with considerable economic consequences for Turkey's southeast region.

13. The irony of the state arriving one day to establish the border of 'Turkey' was the subject of a film, Propaganda (Çetin \& Çetin 1999). In it, villagers who have never had a state ID, let alone a passport, are forced to adapt to the arrival of border guards in the middle of their town, separating friends and families. The mythic town of the film straddling the newly established border is not unlike the situation that faced villages straddling the border between Turkey and Syria, with residents of the Harran plan similarly disconnected from families on the other side of the border in Syria. As several farmers explained, for certain bayram [religious holidays] the government eases passport requirements so that they can travel freely to visit friends and family.

14. To reiterate, I emphasize the southeast as an important border region, and the Harran plain as a border area within this border region both as significant, but results from Harran cannot be thought of as representative of the entire southeast region, given political, ethnic, linguistic, and other differences.

15. With respect to other notable characteristics of the Harran plain, it is also noteworthy that there are high degrees of landlessness in the plain, commonly estimated at approximately $25 \%$ (Ünver 1997a). This percentage was comparable to the overall proportion of survey respondents who reported that they owned no land. The other general citations provided on the southeast also provide information on other notable socio-cultural features of the region, including gender concerns, the aşiret structure, and economic considerations as a region that remains predominantly agricultural and is the site of relatively little economic investment.

16. The GAP channel is a public relations facet of the GAP project, designed to advertise and promote GAP development efforts -from agricultural extension to family planning. Based on my interviews and survey, it is also one of the primary ways that residents are familiar with GAP and 
recognize this as a state program. In the survey, 83 respondents (69\%) said they had heard of GAP, compared to 38 (31\%) who said they did not. In a follow up question, we asked what they think GAP does. Of responses given, thirty identified irrigation and dam building, and a considerable number of others identified the television station. Relatively few also associated GAP with social programs.

17. Encounters with the state in these villages also necessarily include schoolhouses (the first place that students may be required to speak Turkish, and also villages spaces symbolically marked by the Turkish flag as a visible marker of state and nation) (see Kaplan 2006). Interactions with imams also represent less obvious 'contact zones' between villagers and the state, as all imams are state employees and may often represent issues as directed by the Directorate for Religious Affairs. Of course, in other parts of the southeast, especially in mountainous areas, the 'village guard' system represents a very different sort of state presence.

18. Some argue that Özal's concern for and interest in the southeast largely stems from his own Kurdish heritage. Ataman (2002) provides a discussion of the restructuring of Turkish policy vis$\grave{a}$-vis ethnic minorities under Özal's leadership.

19. I do not want to overstate this case, however, given that the Harran plain is both an Arabic speaking region of the southeast (and thus not necessarily as oppositional as the Kurdish and mountainous spaces of the region). Additionally, as the pilot area for irrigation delivery, the Harran plain is somewhat exceptional as a space that is most likely to have received benefits from the project (relative to those sites that were inundated to make way for the infrastructure works, for instance).

20. This was asked as an unprompted open-ended question, and the response was noted. The researcher classified the responses based on whether their answers indicated some benefit to villages or the southeast region, and whether benefits to the state were mentioned in their responses.

21. For instance, only one-third of self-identified 'poor' women considered irrigation to be beneficial, in contrast with approximately $3 / 4$ of the entire survey population who noted irrigation as either being 'very beneficial', or 'beneficial.' Even as the survey cannot be read as statistically significant, nonetheless, these sorts of discrepancies pose interesting questions for consideration in terms of differentiated reception of irrigated-related changes.

22. The first question asked was 'Why do you think the state brought irrigation to your village' (question 30: 'Size göre, devlet köyünüze sulamayı neden getirdi?'). The follow up question was, 'Since irrigation, have your ideas about the state changed? If so, why?' (question 31: 'Sulama geldikten sonra devlet hakkındaki düşünceleriniz değişti mi? Evetse, nasıl?')

23. This is an often-celebrated benefit of irrigation delivery, as many villagers used to travel to Adana for seasonal work as irrigators or cotton pickers. Some villagers still do travel to Adana, noting better pay, but many stay in Harran due to the proximity.

24. See Harris (2006) for discussion of how differentials with respect to livelihoods and landholdings have been retrenched through transition to irrigated economies, and Harris (2008b) for more general discussion on differentiated effects of, and responses to, GAP-related changes among women, the landless, Kurds/ Arabs, and others living and working in the region.

25. In the survey, $72.5 \%$ of respondents answered 'yes' to the question "in your village, is there a problem of unequal land ownership?' Of survey respondents, only $43 \%$ said that they owned their own land.

26. I conducted most interviews with the help of Turkish assistants. Students from a local university also helped administer the survey (however, several among these students also spoke Kurdish and/or Arabic). Throughout the fieldwork, I encountered both very open critique of the state (perhaps enabled by my position as an independent American researcher, viewed as an outsider and as potentially sympathetic to such critique, especially related to the Kurdish issue) and also obvious caution and skepticism as to the purpose and goals of the research (for instance, 
with questions as to whether I was being sent there by the state, and so forth, although such skepticism and distrust was relatively rare).

27. One should not read too much into this comparison, as we do not have adequate details about the sample of the earlier surveys or the way that the earlier survey was implemented (although the earlier survey was also among villages of the Harran plain, and several of our villages overlapped). In terms of this particular discrepancy in responses, a possible explanation is that the earlier surveyors likely provided choices to respondents (upon hearing 'God', it would be less likely for respondents to provide some other answer), while our survey was asked in a way that left all responses open-ended (responses were only later grouped and categorized).

28. Villages of the region are generally portrayed as highly Islamic, and the region generally often supports Islamist or Kurdish political parties.

\section{RÉSUMÉS}

There is theoretical significance to studying states and nations at their metaphorical and literal 'borders'. Focusing on the contested border region of southeastern Anatolia, this chapter highlights the tensions, contradictions, and recent shifts in state-society relations in the rural spaces of the southeast. As I detail, state delivery of irrigated agriculture represents a recent and significant chapter in the evolving state-society relations in this contested border area. With contemporary changes associated with the large-scale Southeastern Anatolia Project (GAP), state influence in rural areas and encounters with the state by rural populations are intensified. This occurs both horizontally, in terms of infiltrating new spaces and life practices, and also vertically, in terms of intensified interaction, such as that associated with the increased incorporation of rural residents into the Turkish economy or the increased dependence of villagers on state services. Reading the state ethnographically through the differentiated responses of villagers to recent irrigation-related changes, my aim is to analyze how the state is lived, in very real terms, in the fabric of everyday life, and to consider what this suggests for understanding state-society relations and the changing citizen subjectivities in the liminal spaces of Turkey's southeast.

\section{INDEX}

Keywords : borders, Harran, Southeastern Anatolia Project (GAP), state-society relations Mots-clés : frontières, Harran, relations Etat-société, Southeastern Anatolia Project (GAP)

\section{AUTEUR}

\section{LEILA M. HARRIS}

Leila M. Harris is a political, social, and cultural geographer who focuses on developmental and environmental change, water politics, and gender and social difference, particularly in Turkey and the Middle East. She is currently an Assistant Professor of Environmental Studies, and 
Gender and Women's Studies, at the University of British Columbia in Vancouver, Canada.

lharris@ires.ubc.ca 